\title{
Extracellular Matrix Promotes the Growth and Differentiation of Murine Hematopoietic Cells In Vitro
}

\author{
Alan Campbell and Max S. Wicha \\ Department of Internal Medicine, Division of Hematology and Oncology, University of Michigan Medical Center, \\ Simpson Memorial Research Institute, Ann Arbor, Michigan 48109 \\ Michael Long \\ Department of Pediatrics and Communicable Diseases, Division of Hematology and Oncology, \\ University of Michigan Medical Center, Ann Arbor, Michigan 48109
}

\begin{abstract}
We have developed a long-term culture system in which murine marrow cells are cultured on a complex extracellular matrix (ECM) that is derived from marrow and extracted with guanidine hydrochloride and dithiothreitol. Marrow cultures were established with fresh murine marrow cells and recharged at 2 wk (week 0). Phase microscopy showed a dramatically increased adherent cell layer development on ECM compared with controls within a week after recharge. By electron microscopy, this adherent layer was composed of numerous reticular cells apparently attached to the ECM which extended cytoplasmic projections to the surrounding hematopoietic cells. Adherent cellularity on ECM-coated dishes increased to 30 times the control values by week 2. Cumulative suspension cells on ECM dishes were eight times controls. ECM influenced both hematopoietic progenitor cell proliferation and differentiation. Adherent colony-forming unit-granulocyte/macrophage and colony-forming unit-megakaryocyte were $>30$ and 15 times the control values, respectively, by week $2(P \leqslant 0.05)$. There were more mature granulocytic and megakaryocytic cells in ECM-coated dishes than in controls at all time points. This new culture system directly demonstrates that ECM is an important component of the hematopoietic microenvironment.
\end{abstract}

\section{Introduction}

The hematopoietic microenvironment is known to influence the growth and differentiation of hematopoietic cells. Although poorly defined, this microenvironment is composed of both cellular and extracellular components. In long-term bone marrow cultures, the maintenance of hematopoiesis is dependent on the establishment of an intact layer of adherent cells that are derived from the marrow stroma (1-3). Such adherent cell layers are capable of elaborating soluble factors which influence hematopoietic proliferation and/or differentiation

Dr. Long is a scholar of the Leukemia Society of America. Address correspondence to Dr. Campbell, University of Michigan, Division of Hematology/Oncology, 102 Observatory.

Received for publication 21 November 1984 and in revised form 12 March 1985.

J. Clin. Invest.

(C) The American Society for Clinical Investigation, Inc.

0021-9738/85/06/2085/06 \$1.00

Volume 75, June 1985, 2085-2090
(4). Little is known, however, about the function of the extracellular components within the hematopoietic microenvironment. There is substantial evidence in a variety of other developmental systems that the extracellular matrix (ECM) ${ }^{1}$ influences cell growth and differentiation (5-7). Recent studies suggest that the ECM also plays a role in the in vitro proliferation and differentiation of hematopoietic cells. Inhibitors of matrix formation are known to decrease stem cell production (8), while compounds stimulating matrix production increase stem cell proliferation (9). Finally, the stromal cell population is known to produce a variety of ECM proteins including fibronectin, laminin, and type IV collagen (10).

We hypothesize that bone marrow-derived ECM plays a crucial role in the development of the hematopoietic microenvironment. In order to test this hypothesis, we have developed a new system of murine long-term marrow cultures established on ECM extracted from bone marrow. We report that this extracellular material promotes rapid formation of an adherent stromal cell layer and, subsequently, proliferation and differentiation of hematopoietic cells. This system demonstrates the importance of ECM in the hematopoietic microenvironment.

\section{Methods}

Preparation of ECM. Femurs and tibias removed from 4- to 6-wk-old rabbits were obtained from Pel-Freeze Biologicals (Rogers, AR). Rabbits were used to ensure sufficient quantities of marrow extract. The marrow was removed and immediately placed in $50 \mathrm{mM}$ Tris buffer (pH 7.4) containing $3.4 \mathrm{M} \mathrm{NaCl}$, leupeptin $(1 \mu \mathrm{g} / \mathrm{ml})$, and soybean trypsin inhibitor $(10 \mu \mathrm{g} / \mathrm{ml})$ (Sigma Chemical Co., St. Louis, MO) to precipitate ECM proteins, a modification of a previously described method (5). This suspension was homogenized in a Brinkman Polytron homogenizer for $30 \mathrm{~s}$ at high speed. The marrow homogenate was centrifuged at $1,500 \mathrm{~g}$ for $10 \mathrm{~min}$ at $4^{\circ} \mathrm{C}$ and the supernatant and fatty layer removed. The pellet was washed exhaustively in $3.4 \mathrm{M}$ $\mathrm{NaCl}$ solution, digested with RNase $(100 \mu \mathrm{g} / \mathrm{ml})$ and DNase $(25 \mu \mathrm{g} /$ $\mathrm{ml}$ ) (Sigma Chemical Co.) in Fisher's medium at $37^{\circ} \mathrm{C}$ for $1 \mathrm{~h}$, and washed in $3.4 \mathrm{M} \mathrm{NaCl}$ solution overnight. The ECM was extracted from the pellet with $20 \mathrm{ml}$ of $50 \mathrm{mM}$ Tris buffer containing $4 \mathrm{M}$ guanidine $\mathrm{HCl}$ and $2 \mathrm{mM}$ dithiothreitol (pH 7.4), which is known to solubilize proteoglycans and other ECM components $(11,12)$. The extract was centrifuged at $1,500 \mathrm{~g}$ for $10 \mathrm{~min}$ and the supernatant

1. Abbreviations used in this paper: CFU-GM, colony-forming unitgranulocyte/macrophage; CFU-Mk, colony-forming unit-megakaryocyte; ECM, extracellular matrix; EHS, Engelbreth-Holm-Swarm; Gdn/DTT, guanidine/dithiothreitol. 
removed and dialyzed exhaustively against distilled water. The extraction procedure was repeated four times and the extracts pooled. $2 \mathrm{ml}$ of this extract containing $\sim 0.4 \mathrm{mg}$ dry weight of insoluble material was pipetted onto $35-\mathrm{mm}$ tissue culture plastic dishes (Becton-Dickinson $\&$ Co.) and allowed to dry overnight. The dishes were sterilized with $500,000 \mathrm{rad}$ of ${ }^{60} \mathrm{Co}$ irradiation.

Fresh marrow cells were obtained from 4- to 6-wk-old male, syngeneic C57/BL6 mice (Charles River Breeding Labs, Inc., Wilmington, MA). Monodispersed nucleated cells $\left(3 \times 10^{6}\right)$ were suspended in $3 \mathrm{ml}$ of Fisher's medium containing $5 \times 10^{-7} \mathrm{M}$ hydrocortisone (Sigma Chemical Co.), $40 \mu \mathrm{g} / \mathrm{ml}$ of gentamicin, and $20 \%$ horse serum (HyClone Laboratories Inc., Logan, UT). Cultures were established on ECMcoated dishes or on control tissue culture dishes. The cultures were incubated at $33^{\circ} \mathrm{C}$ in a humidified atmosphere with $5 \% \mathrm{CO}_{2}$. At 2 wk (week 0 ), all nonadherent cells were gently removed and the cultures recharged with $3 \times 10^{6}$ fresh nucleated marrow cells in $3 \mathrm{ml}$ of Fisher's medium. At weekly intervals thereafter, medium and suspension cells were removed and replaced with fresh medium. At various intervals, the adherent layer was removed by incubation with trypsin-EDTA 1:250 (KC Biologicals) for $1 \mathrm{~min}$ at room temperature. Total nucleated cell counts were performed by hemocytometer and cell viability assessed by trypan blue exclusion. Cytocentrifuged preparations of adherent and suspension cells were stained with Wright stain or acetylcholinesterase (13)

Progenitor cell assays. Short-term assays for granulocyte progenitor cells (CFU-GM) and megakaryocyte progenitor cells (CFU-MK) were performed as previously described $(14,15)$. Briefly, bone marrow cells were cultured as previously described using conditioned medium from WEHI-3 and mouse lung conditioned medium $(16,17)$. Before plating, the bone marrow cells were generally incubated at $37^{\circ} \mathrm{C}$ for $30-60$ min at $\sim 5 \times 10^{6}$ cells $/ \mathrm{ml}$ in McCoy's $5 \mathrm{~A}$ medium containing $10 \%$ fetal calf serum (FCS). Marrow cells were cultured at 30-100 $\times 10^{4}$ cells/ml in 35-mm petri dishes (Becton-Dickinson \& Co.) in modified McCoy's 5A medium containing $10 \%$ FCS and $0.25 \%$ Bactoagar. After incubation $\left(7 \mathrm{~d}, 37^{\circ} \mathrm{C}, 7 \% \mathrm{CO}_{2}, 100 \%\right.$ humidity), petri dishes were removed from the incubator, dried, and stained in situ for acetylcholinesterase activity (18). Colonies were counted at a magnification of 40 .

Electron microscopy. Representative matrix and control dishes were harvested at $\sim 2$ wk postrefeeding and prepared for scanning and transmission electron microscopy, as described (19).

Protein analysis. SDS polyacrylamide gel electrophoresis, after the method of Laemmli (20), was performed on samples of bone marrow guanidine/dithiothreitol (Gdn/DTT) extract, high molecular weight standards (Sigma Chemical Co.), and Gdn/DTT extract of ECM was obtained from the Engelbreth-Holm-Swarm (EHS) tumor, which is known to produce large quantities of the ECM components laminin, type IV collagen, fibronectin, and entactin (12). All gels are run under identical conditions. The gels were stained using silver nitrate as described (21).

\section{Results}

Morphologic characteristics of long-term cultures on matrix substrata. Bone marrow cells cultivated in control dishes (tissue culture plastic) developed islands of adherent cells within 7-10 d. In contrast, ECM supported a more rapid and extensive development of an adherent layer that became confluent within the same time period. ECM derived from the nonhematopoietic tissues EHS tumor and cortical bone (devoid of marrow) did not promote adherent layer formation or hematopoiesis (data not shown). This suggests organ specificity. The adherent layer that developed on marrow-derived ECM was composed of flat, branching cells that formed large areas having a cobblestone appearance. However, relatively few hematopoietic cells were seen in either cultures at this time. After recharging at week 0 , the control dishes showed gradual development of the adherent layer while ECM-coated dishes showed a striking increase in both hematopoietic and stromal cells (Fig. 1, $A$ and $B$ ). This difference was even more evident when the cultures were examined by scanning electron microscopy. In ECM cultures, the adherent cell layer was composed of large branching cells that extended long filamentous projections which encircled hematopoietic cells (Fig. 1, $C$ and $D$ ). Transmission electron microscopy demonstrated that the adherent phase of the ECM culture was composed of several cell layers (Fig. 1, $E$ and $F$ ). The basal layer consisted of flat stromal cells in direct contact with the matrix extract. Hematopoietic cells were seen to overlie this cell layer. They were often in close apposition to the stromal cells.

Cellular proliferation. Although hematopoietic cells were produced throughout the culture period in both ECM and control dishes, there was an eightfold increase in the suspension phase of ECM cultures compared with controls (Fig. 2). In the adherent phase, there was an even greater difference between the cellularity of ECM and control cultures. Within 2 wk of recharging the cultures, there was a 30 -fold increase in the adherent layer cellularity of ECM cultures compared with controls (Fig. 3). A significant difference in adherent cellularity persisted throughout the $6 \mathrm{wk}$ of culture. After week 6 , a decrease in total cellularity occurred in both ECM and control cultures. However, the adherent layer cellularity of the ECM based cultures remained significantly greater than that of controls. In order to establish whether this decrease in cellularity was due to senescence of the adherent layer or stem cell depletion, another set of cultures was recharged a second time at week 6 . These cultures were capable of another round of proliferation which lasted $\sim 3$ wk (data not shown).

Granulocytic and megakaryocytic progenitor cell proliferation. ECM-based cultures sustained greater numbers of hematopoietic progenitor cells than did control cultures (Table I). By week 3, suspension phase CFU-GM were significantly higher in the ECM cultures. In ECM-based adherent layers there were 30-fold more CFU-GM than in the adherent layer of control cultures. Megakaryocyte progenitor cells were also significantly elevated in ECM adherent layers from week 3 to 4 (Table I).

Granulocytic and megakaryocytic differentiation. In order to assess the degree of hematopoietic differentiation, cytocentrifuged preparations were stained for granulocyte morphology (Wright's stain) or for megakaryocytes (acetylcholinesterase stain) and differential counts were performed. The results are shown in Table II. Both suspension and adherent cells from ECM-based cultures showed a higher total number and higher proportion of mature granulocytes (metamyelocytes, bands, polymorphonuclears) than controls. Megakaryocytes were also elevated in both adherent and suspension phases of ECMcoated dishes. By week 3, ECM-based cultures contained $>4,500$ mature megakaryocytes $(80 \%$ of which were in the adherent layer), whereas control cultures contained $<100$ megakaryocytes (data not shown).

Erythroid proliferation and differentiation. No evidence of significant terminal maturation of erythroid cells was seen on microscopic examination of Wright stained suspension or adherent cells. This is consistent with previous work $(22,23)$, which demonstrated that certain manipulations, such as addition of exogenous erythropoietin, anemic mouse serum, or mechanical agitation, are required to induced terminal erythropoiesis in long-term cultures. 

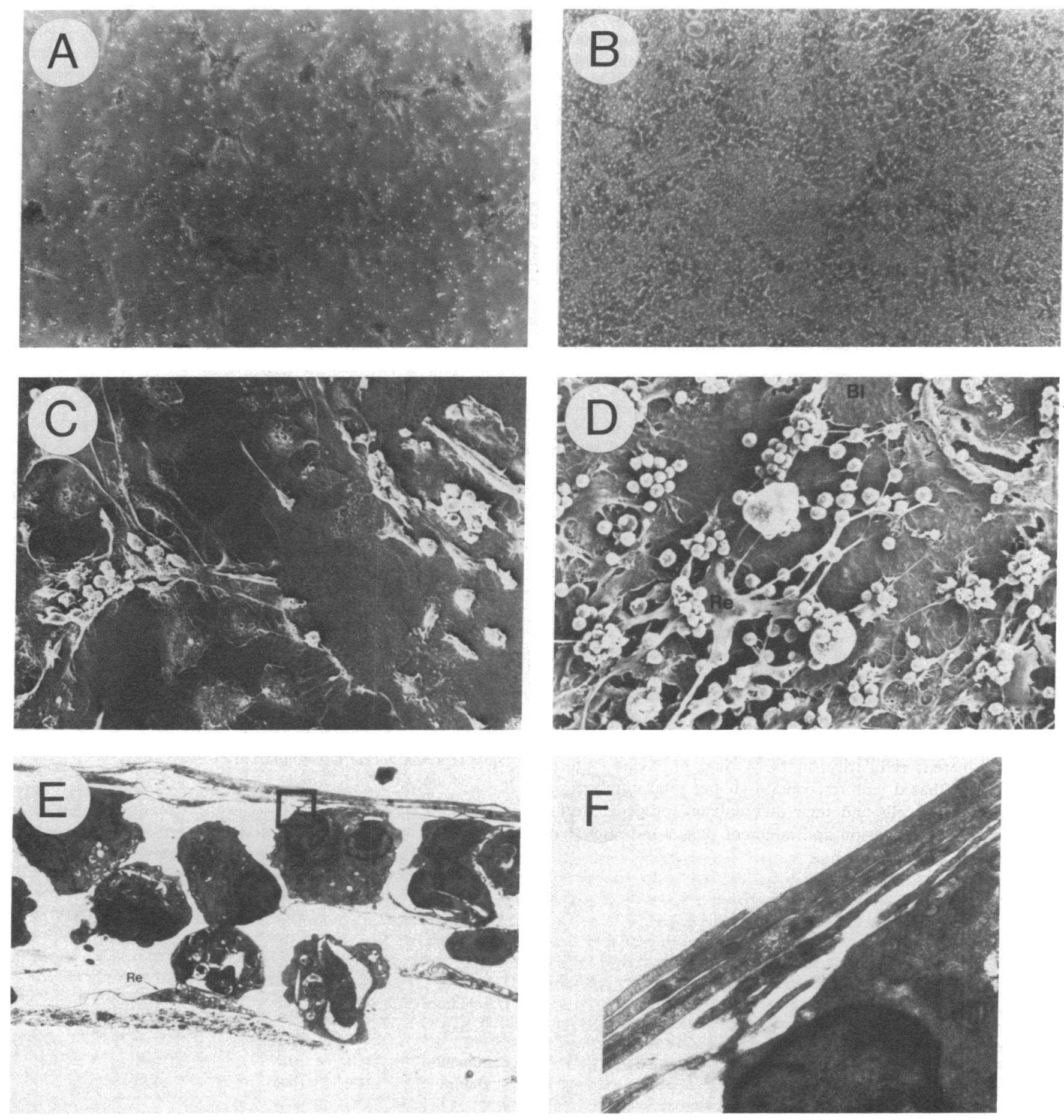

Figure 1. Photomicrographs of long-term cultures. $(A, B)$ Phasecontrast photomicrograph of cultures at week 2. $(A)$ Tissue culture controls. Note relatively sparse hematopoietic islands. $\times 100 .(B)$ ECM-based cultures. Note dense confluent layer of well spread, flattened, adherent cells underlying large aggregations of round hematopoietic cells. $\times 100$. $(C, D)$ Scanning electron microscopy of cultures at week 2. (C) Tissue culture controls. Note scant adherent layer plus small aggregations of hematopoietic cells. $\times 517$. (D) ECM substratum. The ECM is covered by a confluent layer of adherent cells. Associated with these layers are large reticular $(\mathrm{Re})$ and blanket $(\mathrm{Bl})$

cells that are closely associated with hematopoietic cells. $\times 517$. $(E$, $F)$ Transmission electron micrographs of week 3 cultures. $(E)$ Section cut perpendicularly to adherent cell layer. ECM is seen at the lower left hand border. Re, Reticular adventitial cell attached to ECM and extending cytoplasmic processes toward a neighboring cell. Similar cytoplasmic processes are seen surrounding the hematopoietic cells in a manner reminiscent of blanket cells. $\times 1,650$. $(F)$ Higher magnification view of the boxed area in $E$, showing several layers of cytoplasmic processes in contact with each other and covering the lower hematopoietic cells. $\times 16,500$. 


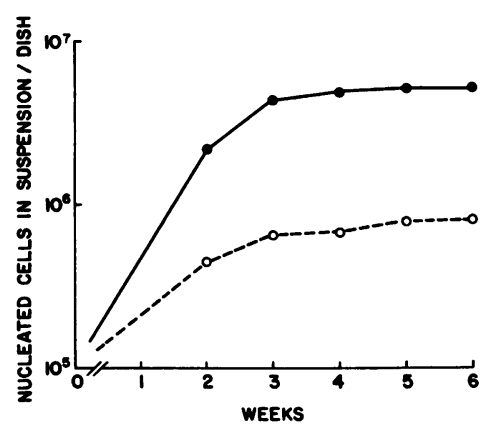

Figure 2. Cumulative suspension cell counts. Longterm marrow cultures were established as described in Methods, and weekly total nucleated suspension cells were determined. Values represent mean cumulative suspension counts of 3-5 individual cultures. $\bullet$, matrix extract; $\circ$, tissue culture plastic.

Molecular characterization of ECM components. In order to characterize components possibly involved in the observed effects of ECM in long-term bone marrow cultures, marrowderived ECM was subjected to electrophoretic separation on a 5\% SDS polyacrylamide gel. A silver stained gel is shown in Fig. 4, and for comparison a gel of EHS-derived ECM is shown. In contrast to the EHS extracellular matrix, bone marrow extracellular matrix contained two major protein bands of $M_{\mathrm{r}} 116,000$ and 135,000 .

\section{Discussion}

Long-term bone marrow cultures established on a substrate of extracellular matrix show enhanced proliferation and differentiation compared with those established on plastic. These cultures are most striking for the rapid development of a densely cellular adherent layer. When these adherent layers are recharged, hematopoietic cells rapidly proliferate in the adherent cell layer, achieving greater cellularity than on plastic. Comparison of ECM with controls shows up to a 30-fold greater adherent cellularity on ECM than on tissue culture plastic. ECM-based cultures contain greater total numbers of both progenitor cells and their differentiated progeny. Comparison of the suspension and adherent phases indicates that

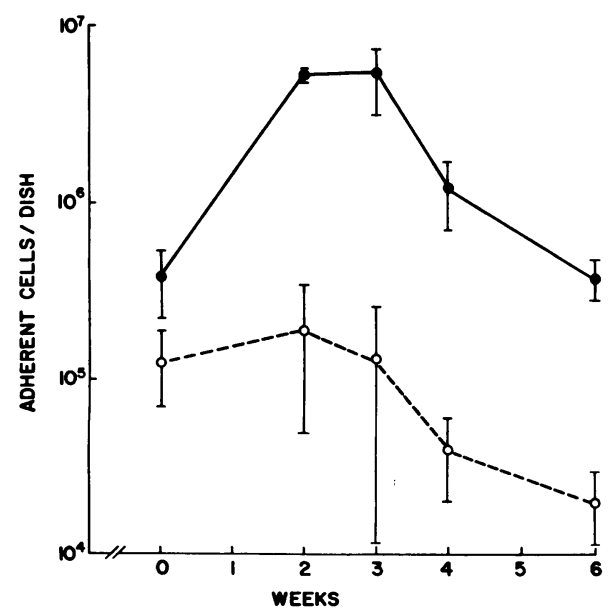

Figure 3. Weekly adherent cell counts. Cultures were established on tissue culture plastic or ECM, and at weekly intervals total nucleated cells in the adherent layer were counted as described in Methods. Values represent the mean $\pm \mathrm{SD}$. At each time point, 3-5 individual cultures were harvested. At week 2 and thereafter the differences between $\operatorname{ECM}(\bullet$, matrix extract) and tissue culture plastic $(0)$ were significant $(P \leqslant 0.05)$.
Table I. Effect of ECM on Hematopoietic Progenitor Cells

\begin{tabular}{|c|c|c|c|c|}
\hline \multirow[b]{2}{*}{ Week } & \multicolumn{2}{|l|}{ Adherent phase* } & \multicolumn{2}{|c|}{ Suspension phaseł } \\
\hline & ECM & $\begin{array}{l}\text { Tissue culture } \\
\text { plastic }\end{array}$ & ECM & $\begin{array}{l}\text { Tissue culture } \\
\text { plastic }\end{array}$ \\
\hline \multicolumn{5}{|c|}{ Granulocyte progenitor cells per culture§ } \\
\hline 0 & NT & NT & $1,780 \pm 329$ & $1,274 \pm 496$ \\
\hline 2 & $3,632 \pm 60^{\prime \prime}$ & $109 \pm 78$ & $496 \pm 109$ & $408 \pm 142$ \\
\hline 3 & $3,606 \pm 1,541^{11}$ & $105 \pm 10$ & $828 \pm 286^{\prime \prime}$ & $227 \pm 31$ \\
\hline 4 & $1,344 \pm 353$ & $78 \pi$ & $626 \pm 217$ & $114 \pi$ \\
\hline \multicolumn{5}{|c|}{ Megakaryocyte progenitor cells per culture** } \\
\hline 0 & NT & NT & $78 \pm 64$ & $24 \pm 38$ \\
\hline 2 & $169 \pm 81^{\prime \prime}$ & $10 \pm 3$ & $23 \pm 18$ & $27 \pm 9$ \\
\hline 3 & $190 \pm 164^{\prime \prime}$ & $8 \pm 3$ & $77 \pm 96$ & $18 \pm 4$ \\
\hline 4 & $206 \pm 249^{\prime \prime}$ & $1 \pm 1$ & $45 \pm 19$ & 5ा \\
\hline
\end{tabular}

Values represent mean \pm SD of 3-5 replicate cultures.

* Adherent phase refers to cells attached to the bottom of the long-term culture dish, either on ECM or plastic, and removed by trypsinization.

¥ Suspension phase refers to cells found suspended in the long-term culture medium.

$\S$ Colony-forming units/granulocyte macrophage were assayed by plating 50,000 cells from either the adherent phase or suspension phase of ECM based or control long-term cultures. 3-5 individual long-term cultures were harvested at each time point, and for each of these 3-5 replicate CFU-GM assays were done.

" $P \leqslant 0.05$ ( $t$ test $)$.

I Values represent pooled data from 1 to 2 individual progenitor cell assays.

** Colony-forming units-megakaryocyte were grown in semisolid agar cultures modified as described (15) so that the cultures were biased toward the formation of megakaryocyte colonies. 3-5 individual long-term cultures were harvested at each weekly time point, and for each of these 3-5 replicate CFU-Mk assays were done.

Table II. Granulocyte Differentiation in ECM and Control Cultures

\begin{tabular}{|c|c|c|c|c|}
\hline \multirow[b]{3}{*}{ Week } & \multicolumn{4}{|c|}{ Total granulocytes per culture $\times 10^{5}$} \\
\hline & \multicolumn{2}{|c|}{ Adherent phase } & \multicolumn{2}{|c|}{ Suspension phase } \\
\hline & ECM & $\begin{array}{l}\text { Tissue culture } \\
\text { plastic }\end{array}$ & ECM & $\begin{array}{l}\text { Tissue culture } \\
\text { plastic }\end{array}$ \\
\hline \multirow{2}{*}{$\begin{array}{l}0 \text { Immature } \\
\text { Mature }\end{array}$} & 0.6 & 0.1 & NT & NT \\
\hline & 1.4 & 0.1 & & \\
\hline \multirow{2}{*}{$\begin{array}{l}1 \text { Immature } \\
\text { Mature }\end{array}$} & NT & NT & 4.7 & 7.1 \\
\hline & & & 14.8 & 10.5 \\
\hline \multirow{2}{*}{$\begin{array}{l}2 \text { Immature } \\
\text { Mature }\end{array}$} & 26.1 & 0.7 & 6.4 & 2.5 \\
\hline & 24.0 & 0.8 & 14.8 & 1.6 \\
\hline \multirow{2}{*}{$\begin{array}{l}3 \text { Immature } \\
\text { Mature }\end{array}$} & 21.2 & 0.3 & 3.0 & 0.6 \\
\hline & 22.8 & 0.0 & 12.3 & 0.7 \\
\hline \multirow{2}{*}{$\begin{array}{l}4 \text { Immature } \\
\text { Mature }\end{array}$} & 4.3 & 0.1 & 3.2 & 0.2 \\
\hline & 6.1 & 0.0 & 8.2 & 0.3 \\
\hline
\end{tabular}

Cultures were established as in Table I. The degree of granulocytic maturation was determined by removing at each time point, adherent phase, or suspension phase cells from 3 to 5 ECM- or plasticbased long-term cultures. The cells were cytocentrifuged, Wright stained, and 400-cell differential counts were performed. Immature cells are defined as blasts, progranulocytes, or myelocytes, and mature cells as metamyelocytes, megakaryocytes, bands, and polymorphonuclears. NT, not tested. 


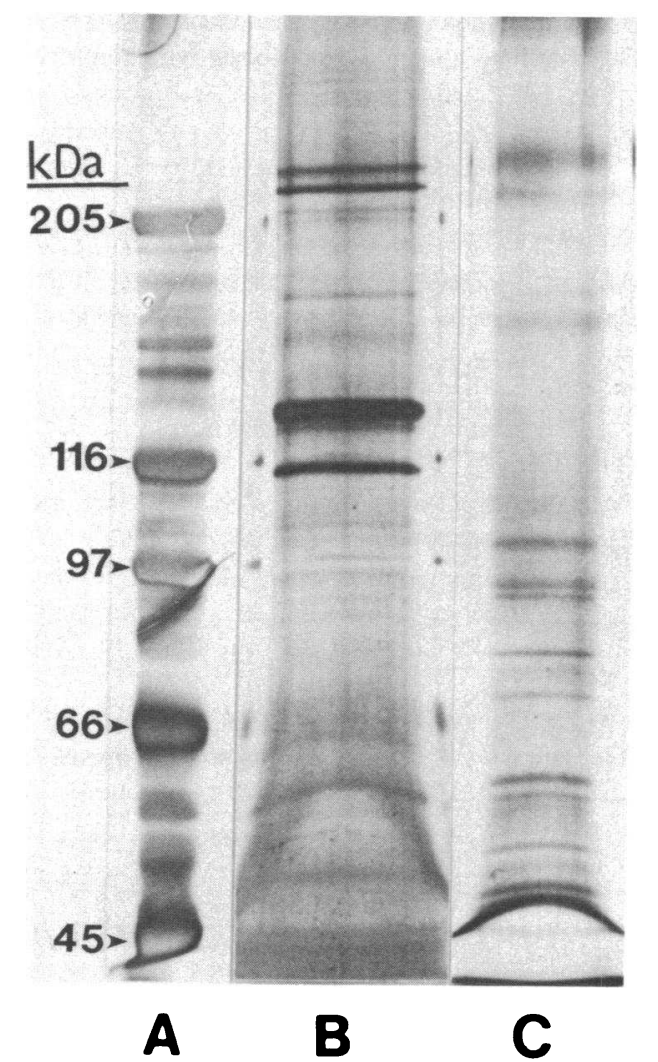

Figure 4. SDS polyacrylamide gel electrophoresis of ECM derived from bone marrow or EHS tumor. Bone marrow and EHS extracellular matrix were electrophoresed on a 5\% polyacrylamide gel under reducing conditions, according to Laemmli (20), and stained with silver nitrate as described (21). The EHS tumor has previously been shown (12) to contain the basement membrane components laminin, type IV collagen, fibronectin, and entactin. $(A)$ High molecular weight standards: myosin $\left(M_{\mathrm{r}} 205,000\right), \beta$-galactosidase $\left(M_{\mathrm{r}} 116,000\right)$, phosphorylase b $\left(M_{\mathrm{r}} 97,400\right)$, bovine albumin $\left(M_{\mathrm{r}} 66,000\right)$, egg albu$\min \left(M_{\mathrm{r}} 45,000\right)$, carbonic annhydrase $\left(M_{\mathrm{r}} 29,000\right)$. (B) Bone marrow extracellular matrix Gdn/DTT extract. Note major protein components at $M_{\mathrm{r}} 116,000$ and $M_{\mathrm{r}} 135,000$. (C) EHS extracellular matrix Gdn/DTT extract. Note absence of $116,000-$ and $135,000-M_{\mathrm{r}}$ protein bands. $\mathrm{kDa}$, molecular weight.

the ECM-induced response was primarily restricted to the adherent cell layer. We hypothesize that ECM is involved in the development of a stromal cell layer that promotes proliferation and differentiation of hematopoietic stem cells to a greater extent than stromal cell layers based on plastic. Also, we have found that the stromal cell layer induced by ECM can be recharged a second time with fresh marrow cells resulting in renewed hematopoietic cell proliferation.

Electrophoretic analysis of marrow-derived ECM shows the presence of major protein constituents which are not present in the basement membrane containing EHS ECM. The functional significance of these bands is currently the subject of investigation.

A major emphasis in the study of the hematopoietic microenvironment in long-term cultures has been the examination of stromal cells and soluble factors. Allen and Dexter (24) have recently emphasized the importance of blanket cells and macrophagelike cells in regulating stem cell proliferation in culture. The former appear to be flat, large, well-spread cells that directly overlie developing hematopoietic cells. Song and Quesenberry (4) have shown that the adherent cell layer is capable of elaborating soluble factors that regulate hematopoiesis. Little is known about the role of ECM in the hematopoietic microenvironment. Sampath and Reddi (11) showed that ECM derived from cortical bone could induce the formation of a bony ossicle containing fully functional hematopoietic tissue when implanted subcutaneously in rats. This inductive property was lost when the ECM was extracted with $4 \mathrm{M}$ guanidine, but regained again when the residue and extract were reconstituted. We previously demonstrated that in long-term cultures, stromal cells are capable of synthesizing and depositing extracellular components such as fibronectin, laminin, and type IV collagen (10). Furthermore, the addition of cis-hydroxyproline (which specifically inhibits collagen synthesis) resulted in a decrease of stem cell number in these cultures (8). Keating et al. (25) found that proteoglycans are also a major component of the adherent layer of long-term cultures. Spooncer and co-workers (9) have shown that stimulation of glycosaminoglycan synthesis with $\beta$-xylosides results in increased total cellularity and stem cell numbers in longterm cultures. These studies emphasize the importance of extracellular matrix in the hematopoietic microenvironment.

Our data suggest the ECM is an important component of the hematopoietic environment. We hypothesize that the role of extracellular matrix is to stimulate soluble factor production by stromal cells. Thus, a complete understanding of the hematopoietic microenvironment must take into account its three major components: the ECM, cellular elements, and soluble factors. The use of extracellular matrix in our cultures represents a new system for the long-term culture of hematopoietic cells. This system provides a powerful tool to study the role of extracellular matrix in the hematopoietic microenvironment.

\section{Acknowledgments}

The authors wish to thank Linda Gragowski and Connie Heffner for their research assistance in this project.

These studies were supported in part by HL-31568 and HD-16721 from the National Institutes of Health, 83-1169 from the American Heart Association, BC-357 from the American Cancer Society, and a grant from the Pardee Foundation.

\section{References}

1. Dexter, T. M., M. A. S. Moore, and A. P. C. Sheridan. 1977. Maintenance of hematopoietic stem cells and production of differentiated progeny in allogeneic and semiallogeneic bone marrow chimeras in vitro. J. Exp. Med. 145:1612-1616.

2. Moore, M. A. S., and T. M. Dexter. 1978. Stem cell regulation in continuous hematopoietic cell culture. Transplant Proc. 10:83-90.

3. Dexter, T. M. 1982. Stromal cell associated hematopoiesis. J. Cell. Physiol. 1(Suppl.):87-94.

4. Song, Z. X., and P. J. Quesenberry. 1984. Radioresistant murine marrow stromal cells: a morphologic and functional characterization. Exp. Hematol. 12:523-533.

5. Wicha, M. S., G. Lowrie, E. Kohn, P. Bagavandoss, and T. Mahn. 1982. Extracellular matrix promotes mammary epithelial growth and differentiation in vitro. Proc. Natl. Acad. Sci. USA. 79:3213-3217.

6. Enat, R., D. M. Jefferson, N. Ruiz-Opazo, Z. Getmaitin, L. Leinwand, and L. Reid. 1984. Hepatocyte proliferation in vitro: its 
dependence on the use of a serum-free hormonally defined medium and substrata of extracellular matrix. Proc. Natl. Acad. Sci. USA. 81: 1411-1415.

7. Bissel, M. J., G. M. Hall, and G. Parry. 1982. How does the extracellular matrix direct gene expression? J. Theor. Biol. 99:31-68.

8. Zuckerman, K. S., R. K. Rhodes, D. D. Goodrum, U. R. Patel, B. Sparks, J. Wells, M. S. Wicha, and L. May. 1985. Inhibition of collagen deposition in the extracellular matrix prevents the establishment of a stroma supportive of hematopoiesis in long-term murine bone marrow cultures. J. Clin. Invest. 75:970-975.

9. Spooncer, E., J. T. Gallagher, F. Krisna, and T. M. Dexter. 1983. Regulation of hematopoiesis in long-term bone marrow cultures. IV. Glycos-aminoglycan synthesis and the stimulation of hematopoiesis by $\beta$-D-xylosides. J. Cell. Biol. 96:510-514.

10. Zuckerman, K. S., and M. S. Wicha. 1983. Extracellular matrix production by the adherent cells of long-term murine bone marrow cultures. Blood. 61:540-547.

11. Sampath, T. K., and A. M. Reddi. 1981. Dissociative extraction and reconstitution of extracellular matrix components involved in local bone differentiation. Proc. Natl. Acad. Sci. USA. 78:7599-7603.

12. Kleinman, M. K., M. L. McGarvey, L. A. Liotta, P. G. Robey, K. Trygvasson, and G. R. Martin. 1982. Isolation and characterization of type IV procollagen, laminin, and heparan sulfate proteoglycan from the EHS sarcoma. Biochemistry. 21:6188-6193.

13. Jackson, C. W. 1973. Cholinesterase as a possible marker of early cells of the megakaryocytic series. Blood. 42:413-421.

14. Pelus, L. M., M. E. Broxmeyer, J. I. Korland, and M. A. S. Moore. 1979. Regulation of macrophage and granulocyte proliferation. J. Exp. Med. 150:277-292.

15. Williams, N., H. Jackson, P. Ralph, and I. Nakoinz. 1981. Cell interactions influencing murine marrow megakaryocytes: nature of the potentiator cell in bone marrow. Blood. 57:157-163.
16. Ralph, P., M. A. S. Moore, and K. Nilsson. 1976. Lysosyme synthesis by established human and murine histocyte lymphoma cell lines. J. Exp. Med. 143:1528-1533.

17. Williams, N., R. R. Eger, H. M. Jackson, and D. J. Nelson. 1982. Two factor requirement for murine megakaryocyte colony formation. J. Cell. Physiol. 110:101-104.

18. Williams, N., H. M. Jackson, R. R. Eger, and M. W. Long. 1981. The separate roles of factors in murine megakaryocyte colony formation. In Megakaryocytes In Vitro: Biology and Precursors. B. Evatt, R. Levine, and N. William, editors. Elsevier Science Publishing Co., Inc., New York. 59-75.

19. Hayat, M. A. 1981. Fixation for Electron Microscopy. Academic Press, Inc., New York. 321.

20. Laemmli, V. K. 1970. Cleavage of structural protein during the assembly of the head of bacteriophage T-4. Nature (Lond.). 227: 680-685.

21. Morrissey, J. H. 1981. Silver stain for proteins in polyacrylamide gels: a modified procedure with enhanced uniform sensitivity. Anal. Biochem. 117:307-310.

22. Dexter, T. M., N. G. Testa, T. Allen, T. Rutherford, and E. Sedwick. 1981. Molecular and cell biologic aspects of erythropoiesis in long-term bone marrow cultures. Blood. 58:699-707.

23. Eliason, J. F., T. M. Dexter, and N. G. Testa. 1982. The regulation of hemopoiesis in long-term bone marrow cultures. III. The role of burst forming activity. Exp. Hematol. 10:444-450.

24. Allen, T. D., and T. M. Dexter. 1984. The essential cells of the hematopoietic microenvironment. Exp. Hematol. 12:517-521.

25. Keating, A., T. Wright, M. Kinsell, and J. W. Singer. 1984. Proteoglycan synthesis by hematopoietic microenvironmental cells. Clin. Res. 320:311 (Abstr.) 